\title{
Burning mouth syndrome - a common dental problem in perimenopausal women
}

\author{
Zuzanna Ślebioda, Elżbieta Szponar \\ Department of Oral Mucosa Diseases, Poznan University of Medical Sciences, Poznan, Poland
}

\begin{abstract}
Burning mouth syndrome (BMS) is characterized by the presence of burning, paresthesia or pain of the oral mucosa in the absence of pathologic lesions revealed during the clinical examination. Moreover, the pain may be accompanied by oral dryness, hypersensitivity to some food compounds and taste disorders. Etiopathogenesis of this condition remains unclear. Potential local causative factors include among the others mechanical irritation, parafunctions and dysfunctions of the stomatognathic system, contact allergy to dental materials and electro-galvanic phenomena. Potential systemic causes include diabetes mellitus, B group vitamin deficiency (vitamins $\mathrm{B}_{1}, \mathrm{~B}_{2}, \mathrm{~B}_{6}$ and $\mathrm{B}_{12}$ ), folic acid and iron deficiency, hormonal imbalance, gastrointestinal diseases, psychiatric and neurological disorders and drug-induced side effects. The hypothesis concerning the role of hormonal changes in the development of BMS seems to be confirmed by a high incidence of this condition in perimenopausal women. Up to now, due to an unclear etiology of the disease, the treatment is very often ineffective and mainly symptomatic, which may exacerbate patient's anxiety and discomfort. In this paper we present the main etiologic factors of the burning mouth syndrome. We discuss the basic diagnostic and therapeutic methods and the influence of hormonal replacement therapy on the course of BMS based on the current medical reports.
\end{abstract}

Key words: burning mouth syndrome, glossodynia, xerostomia, menopause.

\section{Introduction}

Various local and systemic factors may interfere with the oral cavity condition [1-4]. The local homeostasis in the oral region strongly depends on the hormonal balance in the body, as the receptors for sex steroidal hormones, similar to those located in the genital epithelium, were also detected in the oral mucosa and salivary glands [5-8]. During the female lifetime, distinct changes in oestrogen and progesterone activity occur several times. The serum hormonal imbalance in puberty, menstruation, during pregnancy and in the perimenopausal period results in numerous systemic and local symptoms [5, 7, 9, 10]. Characteristic systemic signs in perimenopausal women include hot flashes, related with the disruption of the control mechanisms in hypothalamic thermoregulatory centre, increased sweating at night and emotional lability [7, 10]. A higher risk of osteoporosis, ischaemic heart disease and anaemia has been reported in this age group of females $[7,10]$. Based on the literature, the menopause symptoms localized in the oral region include decreased salivation, higher incidence of periodontitis, candidiasis and jaw fractures due to ongoing osteoporosis and severe pain and burning of the oral mucosa, described as burning mouth syndrome (BMS) or stomatodynia [6, 7, 10-13].

\section{Burning mouth syndrome}

Burning mouth syndrome is a medical entity characterized by burning, numbness or pain of the oral mucosa with a moderate severity and with no evident clinical symptoms [14-17]. The following signs: oral dryness, hypersensitivity to some food compounds and taste disorders may accompany the condition $[1,4,18]$. Most commonly, the burning is located on labial mucosa, especially on the tip of the tongue. The other frequently affected areas include lips, the buccal mucosa, the palate, the pharynx, regions covered with the removable dental appliance's plate and the floor of the mouth. The symptoms usually occur bilaterally $[14,16,18,19]$.

Lamey et al. defined 3 clinical types of the burning mouth syndrome [20]. Type 1 is characterized by the increasing severity of pain during the day - directly after awakening the patient does not feel any pain or discomfort, the symptoms gradually develop during the day and reach the top in the evening. It has been suggested that the aetiology of BMS type 1 may be related with systemic background. The constant pain intensity during the day with no remissions is typical of BMS type 2. The aetiology in this type seems to be mostly related with psychogenic factors. In both discussed types of BMS, the discomfort does not appear at night. In the 
third type of BMS the symptoms occur intermittently and the patients report periods free from pain and burning. According to some authors, the development of the third type of BMS may be related with allergic reactions to food preservatives $[3,20]$.

Burning mouth syndrome occurs more frequently in females than in males (depending on the author, the proportion of female and male patients with BMS rang es between $3: 1$ and $7: 1)[14,18]$. Female predominance in BMS frequency increases with age, which may suggest that the hormonal changes due to menopause play a noted role in the etiopathogenesis of the condition. The mean age of BMS patients is estimated at 50 to 60 years, with the $4-5 \%$ prevalence in the general population. A slightly higher BMS frequency is observed in Europe (7\%), while in Asia and the United States of America it is lower and reaches $2-3 \%$ and $0.7 \%$, respectively $[14,21,22]$. Burning mouth syndrome prevalence among the menopausal women ranges between $10 \%$ and $40 \%$, depending on the research centre [2, 23]. A high discrepancy of the results may partially be caused by different diagnostic criteria used in compared studies. The performance of epidemiologic observation on representative study groups is handicapped by the lack of a uniform, international system of classification and diagnosis of burning mouth syndrome [3, 24].

\section{Etiopathogenesis of burning mouth syndrome}

Burning mouth syndrome is a clinical entity with no clear, multifactorial aetiology $[14,18,19,25]$. The possible causative factors can be divided into local and systemic ones.

The first group is comprised of several oral diseases and conditions, including e.g. fungal, bacterial and viral infections, geographic tongue and lichen planus in its exacerbated, erosive form. The other local predisposing factors that require consideration are trauma and mechanical irritation, parafunctions and dysfunctions of the stomatognathic system, electro-galvanic phenomenon and improperly adjusted prosthetic appliances. Another commonly reported local cause of BMS is contact allergy to dental materials (e.g. methyl-methacrylate (MMA) monomer, nickel sulphate, cobalt chloride and mercury) and food or cosmetic preservatives (cinnamaldehyde, nicotinic acid and propylene glycol) [14, 18, 21].

Systemic causative factors include diabetes mellitus, $B$ group vitamin deficiency (vitamins $B_{1}, B_{2}, B_{6}$ and $B_{12}$ ), folic acid and iron deficiency, hormonal imbalance, menopause, gastrointestinal diseases, conditions with reduced salivation, some medications (e.g. angiotensin converting enzyme inhibitors (ACEI) - captopril and enarenal, angiotensin II receptor blockers and antagonists, chemotherapeutics), psychiatric and neurological disturbances [21, 26, 27]. Many researchers relate the aetiology of BMS with the disruption in receiving and analysing the sensory stimuli on various levels of the central and peripheral nervous system and with the dysfunction of the nigrostriatal system - comparable to the one observed in degenerative disorders with an impaired function of the dopaminergic system (Parkinson's disease) $[19,28]$. Numerous reports confirm also a higher incidence of BMS in depressed, phobic or paranoid patients, in people with personality disorders and living in a high stress environment [1, 29, 30, 31]. Concurrently, it seems that in some cases, psychogenic disorders develop secondarily to BMS as a response to prolonged, ineffective therapy of the oral pain and discomfort [1, 32].

Meanwhile, Scardina et al. demonstrated that also the local microcirculation in the area affected with pain is disturbed in BMS patients. That may also indicate the role of circulatory factors in the etiopathogenesis of the condition [33].

Considering the presence or absence of the above mentioned, possible local and systemic causative factors, it was suggested to introduce a division into primary and secondary burning mouth syndrome [34]. Primary (idiopathic, real) BMS refers to a situation where no local or systemic etiologic factors of the oral burning can be found. Secondary BMS is defined as an oral pain syndrome resulting from some evident local or general medical cause. In the secondary syndrome the treatment is directed to the elimination of the defined causative factor and usually results in rapid improvement of the patient's condition [34, 35].

\section{Diagnosis of burning mouth syndrome}

The diagnosis of burning mouth syndrome is based on a very careful, detailed medical interview and clinical examination $[14,19,35]$. At the beginning, the type and localization of pain need to be classified. Scala et al. defined 5 basic features of the pain in the course of BMS: the pain persists constantly for the last 4-6 months, it is present during most of the daytime and usually spontaneously decreases at night, it does not exacerbate while eating or drinking and it is directly localized on oral mucosa. Additional BMS signs listed by the same authors include taste disorders, xerostomia, paresthesia and personality/mood disorders [35]. A special attention should be paid to the history of systemic diseases, medicines used, habits and addictions. It should be clarified whether the patient uses any prosthetic appliance. If yes, the type, age of the denture and the patient's hygienic customs related to the appliance should be noted and discussed.

In burning mouth syndrome, no evident, clinical pathologic symptoms appear on the oral mucosa during the clinical examination [10]. The presence of erythema, erosions, ulcers and removable or non-removable coat- 
ings indicate the infectious, inflammatory or traumatic cause of the oral discomfort. In those cases, the initial diagnosis of burning mouth syndrome should be modified and the patient should receive an appropriate treatment suitable for the cause of the disease [14]. In the clinical examination some oral conditions, which may be accompanied by the pain and burning, need to be considered. It includes e.g. candidiasis, lichen planus, geographic tongue, recurrent aphthous stomatitis, pemphigus and contact allergic mucositis induced by dental materials $[6,14]$. In further diagnostic steps, the function of the temporo-mandibular joint and the masseters' tension should be evaluated. A careful teeth examination and assessment of the occlusal conditions are required to exclude the tooth-related pain cause. In patients undergoing prosthetic treatment, the condition of currently used dentures should be checked and the presence of denture stomatitis should be excluded [14, 35].

Recommended additional laboratory tests include full blood count, evaluation of blood serum levels of folic acid, iron, vitamins B and steroid sex hormones and glycaemia. Oral swab and culture are indicated to exclude candidiasis and infections with non-physiologic oral bacteria. Salivary glands tests (sialometric and sialochemical analysis) allow to detect disturbances in saliva production and composition [15, 16, 19]. Several researchers emphasize the role of disturbances in the central and peripheral nervous system function in the etiopathogenesis of BMS, therefore the neurologic observation seems to be also indicated in patients with this condition $[19,28,36]$.

\section{Treatment of burning mouth syndrome}

Due to the multifactorial nature of the BMS aetiology, its treatment requires co-operation of specialists in various fields of medicine and dentistry. That makes it a diagnostic and therapeutic challenge. The key point is to detect all the potential local and systemic causative factors and to define whether the patient suffers from the primary or secondary BMS.

The causative treatment of the secondary BMS comprises elimination of the local etiologic factors, e.g. fungal and bacterial oral infections, irritation due to electro-galvanic phenomenon or ill-fitting dental appliances and treatment of the occlusal dysfunctions. On the other hand, the therapy of detected systemic diseases potentially related to the oral burning and pain, like diabetes mellitus and nutritional deficiencies, needs to be implemented. The improvement of the general health condition and the elimination of local irritants results in the remission of symptoms in a significant part of the patients with secondary BMS $[11,37,38]$.

In the case of primary burning mouth syndrome the treatment is mainly symptomatic and based on softening the pain and concurrent signs. The application of local and systemic analgesics (lidocaine hydrochloride, benzocaine, benzydamine) is recommended. Additionally, topical agents with coating properties, composed of chamomile and linseed, and available in form of gels, ointments and aerosols may be used. In concordant xerostomia some topical moisturizing agents with carboxymethylcellulose and enzymes as those present in natural saliva, like lactoferrin and lactoperoxidase, can be applied. It was also proved that antidepressants exhibit a moderate effectiveness in the treatment of pain syndromes [19, 24, 37]. Decrement in pain severity in the course of BMS was observed after benzodiazepines (clonazepam, diazepam), tricyclic antidepressants (TCA) (amitriptyline, doxepin) and selective serotonin reuptake inhibitors (SSRI) (sertraline, paroxetine) [2, 19, 24, 37]. The adverse effect of sertraline in the management of the oral discomfort in perimenopausal women was however reported by Grady et al., who observed that the drug did not eliminate periodic hot flashes and increased the oral dryness [39]. Meanwhile, the promising results were presented by Femiano et al., who attempted to treat BMS with alpha lipoic acid (ALA). This compound belongs to a group of antioxidants with neuroprotective and stimulating effects on the neuronal growth factor (NGF) [15]. In patients with BMS, in whom concomitant neurological disturbances similar to those typical of Parkinson's disease were revealed during neurological observation, a therapy with levodopa and bupropion - a dopamine reuptake inhibitor - may be considered [19].

People with burning mouth syndrome are motivated to obey the oral hygiene rules meticulously and to eliminate addictions (nicotinism, alcohol overuse) [16, 19]. Mouth-rinses with alcohol are also contraindicated as they may additionally dry and irritate the oral mucosa. Spicy and salty food should be limited in the diet [19].

\section{Influence of hormonal replacement therapy on the course of burning mouth syndrome}

The influence of hormonal replacement therapy on the oral pain and burning intensity in BMS perimenopausal women raises lot of controversy and the results of international studies remain conflicting. The comparative analysis based on randomized epidemiological data and evaluating the impact of particular hormonal replacement therapy (HRT) types on the oral cavity condition has not been performed up to now [6]. After the administration of HRT in 149 menopausal women with BMS, Wardrop et al. observed the improvement of the oral condition in $70 \%$ of the examined subjects [40]. Forabosco et al. described a decrease of pain in the oral mucosa in 15 out of 27 perimenopausal women who underwent estradiol supplementation and in 12 out of 22 perimenopausal women treated 
with estriol. Concurrently, the authors emphasized that the rapid decrement in the steroid sex hormones level during the menopause may lead to the discomfort and burning sensation only in some women as generally the number of nuclear receptors for sex steroids in the oral cavity is rather low [8]. Meanwhile, Tarkkila et al., based on the results of a questionnaire performed on 3173 perimenopausal women, did not confirm the positive impact of the hormonal replacement therapy on the oral cavity condition. According to the participants of their study, the use of HRT did not influence the severity of xerostomia and did not prevent burning and pain of the oral mucosa [41]. Dissimilar results were achieved by Yalçin et al. [42] and Jansson et al. [43]. In their observations, dry mouth affected a higher percentage of menopausal women not using any type of hormonal replacement therapy than women on HRT. Kaczmarek et al. stated that the implementation of individually adjusted HRT in 16 volunteers recruited from a group of perimenopausal women with concomitant oral discomfort helped to improve some of salivary parameters. Already after one month from the beginning of the treatment, the flow of unstimulated saliva was increased, while the total protein and calcium salivary content was reduced. There was also observed an elevation in the concentration of salivary peroxidase an important antioxidant which limits the bacterial, fungal and viral growth in the oral environment. After the treatment, the levels of the above mentioned salivary parameters in the study group were comparable to those reached in the control group of 16 females in reproductive age. Meanwhile, HRT did not influence the $\mathrm{pH}$ level in the oral cavity of the study group' volunteers [9].

\section{Conclusions}

Burning mouth syndrome is a condition, which may severely decrease the quality of life in perimenopausal women [44]. Due to its multifactorial and still not fully understood aetiology, the therapeutic procedures in BMS require the cooperation of specialists in various fields of medicine and dentistry. Very often the treatment options do not ensure full recovery, which raises stress and frustration in some patients. The imbalance in oestrogen and progesterone serum levels in the perimenopausal period may in some women also induce anxiety and depression. Psychogenic factors play an important role in the development of BMS, therefore psychological care seems to be another important element in the management of this condition.

\section{Disclosure}

Authors report no conflicts of interest.

\section{References}

1. Eli I, Kleinhauz M, Baht R, et al. Antecedens of burning mouth syndrome (glossodynia) - recent life events vs. psychopatologic aspects. J Dent Res 1994; 73: 567-572.

2. Grushka M, Epstein JB, Gorsky M. Burning mouth syndrome. Am Fam Physician 2002; 65: 615-620.

3. López-Jornet P, Camacho-Alonso F, Andujar-Mateos P, et al. Burning mouth syndrome: update. Med Oral Patol Oral Cir Bucal 2010; 15: e562-568.

4. Formaker BK, Frank ME. Taste function in patients with oral burning. Chem Senses 2000; 25: 575-581.

5. Machowska A, Szlachcic A, Brzozowski T, et al. Wpływ żeńskich i męskich hormonów płciowych na proces gojenia się doświadczalnych wrzodów błony śluzowej języka i żołądka. Przew Lek 2004; 10: 38-47.

6. Meurman JH, Tarkkila L, Tittinen A. The menopause and oral health. Maturitas 2009; 63: 56-62.

7. Friedlander $\mathrm{AH}$. The physiology, medical management and oral implications of menopause. J Am Dent Asssoc 2002; 133: 73-81.

8. Forabosco A, Criscuolo M, Coukos G, et al. Efficacy of hormone replacement therapy in postmenopausal women with oral discomfort. Oral Surg Oral Med Oral Pathol 1989; 67: 535-540.

9. Kaczmarek U, Pietkiewicz-Rzepa A, Pietkiewicz A. Ocena wpływu hormonalnej terapii zastępczej na wybrane parametry śliny kobiet w wieku okołomenopauzalnym - doniesienie wstępne. Dent Med Probl 2005; 42: 83-87.

10. Frutos R, Rodriguez $S$, Miralles $L$, et al. Manifestaciones orales y manejo odontológico durante la menopausia. Medicina Oral 2002; 7: 26-35.

11. Golecka-Bąkowska M, Mierzwińska-Nastalska E, Gadomska H, et al. Ocena współwystępowania grzybów drożdżopodobnych w różnych ontocenozach u pacjentek w wieku okołomenopauzalnym użytkujących uzupełnienia protetyczne. Protet Stomatol 2010; 60: 82-94.

12. Ben Aryeh H, Gottlieb I, Ish-Shalom S, et al. Oral complaints related to menopause. Maturitas 1996; 24: 185-189.

13. Ostrowski J. Palenie w obrębie jamy ustnej i gardła nie jest pozaprzełykowym objawem choroby refluksowej przełyku. Gastroenterologia Kliniczna 2010; 2: 112-116.

14. Mendak M. Algorithm for diagnosis and treatment of the primary and secondary burning mouth syndrome depending on etiological factors. Dent Med Probl 2006; 43: 585-595.

15. Femiano F, Lanza A, Buonaiuto C, et al. Burning mouth disorder (BMD) and taste: a hypothesis. Med Oral Patol Oral Cir Bucal 2008; 13: E470-474.

16. Mock D, Chugh D. Burning mouth syndrome. Int J Oral Sci 2010; 2: 1-4.

17. Minguez-Sanz MP, Salort-Llorca C, Silvestre-Donat FJ. Etiology of burning mouth syndrome: a review and update. Med Oral Patol Oral Cir Bucal 2011; 16: e144-148.

18. Gao J, Chen L, Zhou J, et al. A case-control study on etiological factors involved in patients with burning mouth syndrome. J Oral Pathol Med 2009; 38: 24-28.

19. Budrewicz S, Kosiorowska-Gawron E, Kostewicz M. Etiopatogeneza, diagnostyka i leczenie zespołu pieczenia jamy ustnej w ujęciu neurologicznym. Dent Med Probl 2006; 43: 109-113.

20. Lamey P-J, Lamb AB. Prospective study of aetiological factors in burning mouth syndrome. Br Med J 1988; 296: 1243-1246.

21. Palacios-Sánchez MF, Jordana-Comín X, García-Sívoli CE. Burning mouth syndrome: A retrospective study of 140 cases in a sample of catalan population. Med Oral Patol Oral Cir Bucal 2005; 10: 388-393.

22. Suzuki N, Mashu S, Toyoda M, et al. Oral burning sensation: prevalence and gender differences in a Japanese population. Pain Pract 2010; 10 : 306-311.

23. Cavalcanti DR, Birman EG, Migliari DA, et al. Burning mouth syndrome: clinical profile of Brazilian patients and oral carriage of Candida species. Braz Dent J 2007; 18: 341-345.

24. Ship JA, Grushka M, Lipton JA, et al. Burning mouth syndrome: an update. J Am Dent Assoc 1995; 126: 842-853.

25. Guinn AC, Rouleau TS, Brennan MT. Burning tongue and lips. J Am Dent Asssoc 2010; 141: 541-545.

26. Marques-Soares MS, Chimenos-Küstner EC, Subirá-Pifarrè CS, et al. Association of burning mouth syndrome with xerostomia and medicines. Med Oral Patol Oral Cir Bucal 2005; 10: 301-308. 
27. Salort-Llorca C, Mínguez-Serra MP, Silvestre FJ. Drug-induced burning mouth syndrome: a new etiological diagnosis. Med Oral Patol Oral Cir Bucal 2008; 13: E167-170.

28. Koszewicz M, Budrewicz S, Kosiorowska-Gawron E, et al. Diagnostyka elektrofizjologiczna w zespole pieczenia jamy ustnej u pacjentów z chorobą Parkinsona. Neurol Neurochir Pol 2008; 42: S31-35.

29. Mendak M, Konopka T. Wybrane testy psychologiczne u pacjentów z zespołem pieczenia jamy ustnej lub chorobą Parkinsona. Czas Stomatol 2010; 63: 610-620.

30. Soto-Araya M, Rojas-Alcayaga G, Esguep A. Asociacion entre alteraciones psicologicas y la presencia de liquen plano oral, sindroma boca urente y estomatitis aftosa recidivante. Med Oral 2004; 9: 1-7.

31. Takenoshita M, Sato T, Kato Y, et al. Psychiatric diagnoses in patients with burning mouth syndrome and atypical odontalgia referred from psychiatric to dental facilities. Neuropsychiatr Dis Treat 2010; 6: 699-705.

32. Bogetto F, Maina G, Ferro G, et al. Psychiatric comorbidity in patients with burning mouth syndrome. Psychosom Med 1998; 60: 378-385.

33. Scardina GA, Pisano T, Carini F, et al. Burning mouth syndrome: an evaluation of in vivo microcirculation. J Am Dent Asssoc 2008; 139: 940-946.

34. Mendak M, Konopka T, Bogucki A, et al. Uwarunkowania psychologiczne i kliniczne zespołu pieczenia jamy ustnej. Dent Med Probl 2005; 42: 595-603.

35. Scala A, Checchi L, Montevecchi M, et al. Update on burning mouth syndrome: overview and patient management. Crit Rev Oral Biol Med 2003; 14: 275-291.
36. Siviero M, Teixeira MJ, Tesseroli de Siqueira JT, et al. Central mechanisms in burning mouth syndrome involving the olfactory nerve: a preliminary study. Clinics 2011; 66: 509-512.

37. Lewandowski B, de Sternberg Stojałowski S, Wojnar J. Zespół piekących ust: etiopatogeneza, diagnostyka i leczenie. Przegląd Medyczny Uniwersytetu Rzeszowskiego i Narodowego Instytutu Leków w Warszawie 2011; 1: 108-114.

38. Cerchiari DP, Dutra de Moricz R, Alves-Sanjar F, et al. Burning mouth syndrome: etiology. Rev Bras Otorrinolaringol 2006; 72: 419-424.

39. Grady D, Cohen B, Tice J, et al. Ineffectiveness of sertraline for treatment of menopausal hot flushes: a randomized controlled trial. Obstet Gynecol 2007; 109: 823-830.

40. Wardrop RW, Hailes J, Burger $\mathrm{H}$, et al. Oral discomfort at menopause. Oral Surg Oral Med Oral Pathol 1989; 67: 535-540.

41. Tarkkila L, Linna M, Tittinen A, et al. Oral symptoms at menopause - the role of hormone replacement therapy. Oral Surg Oral Med Oral Pathol Oral Radiol Endod 2001; 92: 276-280.

42. Yalçin F, Gurgan S, Gul G. Oral health in postmenopausal Turkish women. Oral Health Prev Dent 2006; 4: 227-233.

43. Jansson C, Johansson S, Lindh-Astrand L, et al. The prevalence of symptoms possibly related to the climacteric in pre- and postmenopausal women in Linköping, Sweden. Maturitas 2003; 45: 129-135.

44. Skiba M, Kusa-Podkańska M, Wysokińska-Miszczuk J. Wpływ stanu jamy ustnej na jakość życia osób w starszym wieku. Gerontol Pol 2005; 13: 250-254. 